\title{
Incidental Focus-on-Form Characteristics: Predicting Learner Uptake. Formulaic vs. Non-Formulaic Forms
}

\author{
Leila Gholami \\ Department of English \\ Arizona State University \\ lgholami@asu.edu
}

\begin{abstract}
A substantial number of studies have investigated the efficacy of incidental focus on form (FonF) measured through (successful) uptake rate in teacher-learner interactions in communicative contexts and have established a link between learners' (successful) uptake of linguistic forms and their second language learning. In this line of research, the analysis of uptake and FonF characteristics mediating learners' (successful) uptake has been limited to linguistic forms of grammar, vocabulary, pronunciation, and spelling (non-formulaic forms). However, formulaic sequences, including idioms, collocations, lexical bundles, and compounds (formulaic forms), have received scant attention in FonF research. This study examined incidental FonF characteristics that best predicted learners' (successful) uptake of formulaic forms and compared the findings with the variables that mediate the (successful) uptake of nonformulaic forms targeted in focus-on-form episodes (FFEs). To this end, 30 hours of audio-recorded teacher-learner interactions in primarily communicative activities from English as a foreign language classes were examined. The findings showed that learners' attention was drawn to non-formulaic forms more frequently than formulaic forms in FFEs. Nonetheless, learners produced (successful) uptake more often when formulaic forms were targeted in FFEs than non-formulaic forms. Logistic regression analyses showed that FonF characteristics that predicted learners' production of (successful) uptake were different for formulaic vs. non-formulaic forms targeted in FFEs.
\end{abstract}

Keywords: EFL; Focus on form; formulaic sequences; incidental FonF characteristics; successful uptake.

\section{Resumen}

Un número considerable de estudios ha investigado la eficacia del enfoque incidental en la forma (FonF) medida a través de la tasa de asimilación (exitosa) en las interacciones entre el profesor y el alumno en contextos comunicativos y han 
establecido un vínculo entre la asimilación (exitosa) de formas lingüísticas por parte de los alumnos y su aprendizaje de una segunda lengua. En esta línea de investigación, el análisis de las características de asimilación y FonF que median en la asimilación (exitosa) de los alumnos se ha limitado a las formas lingüísticas de gramática, vocabulario, pronunciación y ortografía (formas no formulaicas). Sin embargo, las secuencias de fórmulas, incluidas las expresiones idiomáticas, las colocaciones, los conjuntos léxicos y los compuestos (formas de fórmulas), han recibido escasa atención en la investigación del FonF. Este estudio examinó las características incidentales del FonF que mejor predijeron la asimilación (exitosa) de las formas formulaicas por parte de los alumnos y comparó los resultados con las variables que median en la asimilación (exitosa) de las formas no formulaicas que son objeto de episodios de enfoque en la forma (FFE). Para ello, se examinaron 30 horas de interacciones profesor-alumno grabadas en audio, principalmente en actividades comunicativas de clases de inglés como lengua extranjera. Los resultados mostraron que la atención de los alumnos se dirigía a las formas no formulaicas con más frecuencia que a las formulaicas en los episodios de FonF. Sin embargo, los alumnos producían una captación (exitosa) más a menudo cuando las formas formulaicas eran el objetivo de los FFEs que cuando lo eran las formas no formulaicas. Los análisis de regresión logística mostraron que las características del FonF que predecían la producción de asimilación (exitosa) por parte de los alumnos eran diferentes para las formas formulaicas frente a las formas no formulaicas dirigidas a los episodios de enfoque en la forma (FFE).

Palabras clave: ILE; enfoque en la forma; secuencias formulaicas,;características de enfoque en la forma incidentales; captación exitosa.

\section{Introduction}

Incidental focus on form (FonF) refers to directing learners' attention to linguistic forms as they arise spontaneously in primarily communicative interactions (Long, 1996). Successful uptake is used in descriptive FonF studies as a metric for the potential efficacy of incidental FonF in facilitating second language (L2) learning (e.g., Ellis, Basturkmen, \& Loewen, 2001; Li \& Vuono, 2019; Loewen, 2004). Uptake is characterized as "learners' responses to the provision of feedback after either an erroneous utterance or a query about a linguistic item within the context of meaningfocused language activities" (Loewen, 2004: 153). Successful uptake refers to learners' target-like modification of their utterances following FonF, and learners' non-targetlike modification of their original output is termed as unsuccessful uptake (Egi, 2010). Successful uptake is "facilitative of acquisition" (Ellis et al.: 287, emphasis in original) by "providing opportunities for learners to proceduralize target language knowledge already internalized in the declarative form" (Lyster, 1998: 191). According 
to Schmidt's (1995) noticing hypothesis, linguistic forms that are noticed are learned more effectively. Learners' production of successful uptake following FonF has been found to be the evidence of their noticing target forms (e.g., Egi, 2010; GurzynskiWeiss \& Baralt, 2015).

A number of variables such as the type of FonF, the timing of FonF, type of corrective feedback, and other pedagogical choices in the provision of incidental FonF have been found to influence the rate of uptake and its quality (i.e., successful and unsuccessful uptake) (Ellis et al., 2001; Loewen, 2004). Previous FonF studies have examined FonF, uptake, and the characteristics that mediate learners' production of (successful) uptake in linguistic forms limited to grammar, vocabulary, pronunciation, and spelling (non-formulaic forms) (e.g., Ellis et al., 2001; Loewen, 2004). However, to date, no studies have examined FonF characteristics predicting learners' production of (successful) uptake in relation to formulaic sequences (FSs) including idioms, collocations, lexical bundles, and compounds (formulaic forms).

FSs are described as "phrases that are conventional pairings of forms with units of meaning in a speech community" (Buerki, 2016: 21). The significance of FSs in L2 development lies in the pervasiveness of FSs in natural language discourse, communicative functions of FSs, rapid processing of FSs, and the use of FSs as indicative of native-like proficiency (Wray, 2019). It is important to examine the variable predicting learners' (successful) uptake of FSs because of the key role of FSs in communicative language use (Wray, 2019) and the association between learners' successful uptake of linguistic forms and their L2 learning (Loewen, 2004). Therefore, this study examined incidental FonF characteristics that best predicted learners' (successful) uptake of formulaic forms and compared the findings with the variables that mediate the (successful) uptake of nonformulaic forms targeted in incidental FonF.

\section{Literature review}

\subsection{Focus on form and uptake}

Incidental FonF is divided into reactive and preemptive types (Ellis et al., 2001). In reactive FonF, learners are provided with corrective feedback in response to their non-target-like output (Loewen, 2004). In preemptive FonF, either the learner (student-initiated) or the teacher (teacher-initiated) takes the initiative to shift learners' attention to forms by raising a query or making a comment on a form regardless of an error occurrence (Loewen, 2004). The efficacy of incidental FonF in promoting L2 learning has been measured by uptake and successful uptake rate in descriptive studies (e.g., Ellis et al., 2001; Loewen, 2004; Lyster, 2001). 
The significance of (successful) uptake in L2 learning largely derives from the role of noticing (Schmidt, 1995) and pushed output (Swain, 1995) assumed in L2 development. Swain (1995) argues that pushing learners to produce language encourage them to notice the gap in their interlanguage. Schmidt (1995) maintains that learners' noticing the mismatch between their interlanguage and the target language is conducive to restructuring interlanguage toward target forms. The learners' production of (successful) uptake following FonF is a form of pushed output (Egi, 2010) and the evidence of their noticing target forms (Gurzynski-Weiss \& Baralt, 2015).

The incidence of uptake and its quality (i.e., successful and unsuccessful uptake) have been found to be contingent on different pedagogical choices in the provision of incidental FonF (e.g., Ellis et al., 2001; Loewen, 2004). Investigating form limited to vocabulary, grammar, and pronunciation, Ellis et al. (2001) found that (successful) uptake rate varied depending on the type of incidental FonF (i.e., reactive vs. preemptive FonF), the source of FonF (i.e., a problem with communication vs. a problem with the accuracy of the form), and complexity of FonF (i.e., whether attention to form involved several complex moves vs. simple moves). Loewen (2004) found that characteristics such as type of feedback (eliciting target forms from learners vs. providing them with target forms) and timing of FonF (immediate vs. delayed) influenced both the production of uptake and the successfulness of it. The investigation of FonF characteristics that mediate learners' production of (successful) uptake following FSs is a gap in FonF studies.

\subsection{Formulaic sequences}

Various types of FSs include collocations (make money), idioms (make a killing), proverbs (let's make hay while the sun shines), binomials (bride and groom), lexical bundles (as a consequence), compounds (chain store), and pragmatic formulas (nice to meet you) (Siyanova-Chanturia, 2019). FSs are pedagogically important for L2 development based on the following findings. The findings of corpus linguistics attest that FSs are prevalent in natural language use (Erman \& Warren, 2000). Pragmatic formulas (how do you do?) play a key role in performing pragmatic and discourse functions (Kecskes, 2016). The use of FSs fosters fluency as FSs are processed holistically, obviating the need to generate language in a word-for-word fashion from scratch (Siyanova-Chanturia, 2019). FSs also maximize accuracy as FSs are fixed and long chunks allowing for few or no modifications (Wray, 2019).

However, there is a consensus that even advanced L2 learners' knowledge of formulaic language lags behind that of grammar and single-word vocabulary (Meunier, 2012; Sinclair, 1991; Wray, 2019). Meunier (2012) argues that despite the importance 
of FSs in L2 development, they have not figured prominently in language pedagogy due to the traditional emphasis on vocabulary and grammar. One way to facilitate L2 learners' acquisition of FSs is to raise their attention to FSs through incidental FonF and to promote learners' noticing and (successful) uptake of target FSs. Gholami and Gholami (2018) investigated the occurrence of (successful) uptake in 36 hours of communicative interactions and found that learners tended to produce (successful) uptake more often following target formulaic forms than non-formulaic ones. Investigating linguistic form limited to grammar, pronunciation, and vocabulary, Ellis et al. (2001) and Loewen (2004) found FonF characteristics such as the timing of FonF (immediate vs. delayed), type of FonF (reactive vs. preemptive), type of corrective feedback (elicitation vs. provision of correct target form), etc., mediated the occurrence of (successful) uptake in incidental FonF. To the best of the researcher's knowledge, to date, no studies have examined FonF characteristics that mediate learners' (successful) uptake of formulaic forms and compared the findings with the variables that predict learners' (successful) uptake of non-formulaic forms. The investigation of variables predicting learners' successful uptake of FSs is important given that learners' production of successful uptake has been associated with their noticing target forms and L2 learning (Egi, 2010; Loewen, 2004). Therefore, this study examined incidental FonF characteristics that mediate learners' provision of (successful) uptake following formulaic vs. non-formulaic forms through the following research questions:

1. How often does (successful) uptake occur in incidental focus-on-form episodes (FFEs) with formulaic vs. non-formulaic foci in three advanced English as foreign language $(\mathrm{EFL})$ classes?

2. What characteristics of incidental FonF best predict learners' production of (successful) uptake in FFEs with formulaic vs. non-formulaic foci?

\section{Method}

\subsection{Study context}

This study was conducted in an intensive adult EFL program in a language school in Urmia, Iran. The participants included a total of six teachers $(\mathrm{M}=31.5, \mathrm{SD}=3.2)$ teaching six intact classes, and 68 learners $(M=27.3, S D=3.7)$. The learners were of Farsi $(n=19)$, Azeri $(n=36)$, and Kurdish $(n=13)$ language backgrounds. The language school offers general English classes at all proficiency levels. The learners had three to nine years of the language learning experience. Data were collected from six advanced level classes from different sections of the same course with the same 
textbook and syllabus. The learners were placed in the advanced level classes based on their scores on an IELTS test created in house and administered by the school officials. The learners' mean scores on sections of the IELTS placement test (with 0-9 band score range) were 8.6 in listening, 8.2 in reading, 8 in writing, and 7.6 in speaking. Based on the researcher's evaluation of the classroom discourse using the American Council on the Teaching of Foreign Languages proficiency guidelines (2012) and learners' test scores on the placement IELTS test, the learners were assessed to be approximately at Advanced-low to Advanced-mid proficiency levels.

Six classes were taught by six EFL teachers for whom English is an L2. Their teaching experience ranged from five to 17 years. The teachers held bachelor's, master's, and doctorate degrees in TEFL. TEFL degree programs in Iran are universitylevel programs offering general English courses and disciplinary courses on applied linguistics, second language acquisition, language assessment, and research methods in these domains. With no experience living or teaching in an English-speaking country, the teachers taught EFL in public and private schools at different proficiency levels. Unlike the public schooling system in Iran that aims to prepare students for the discrete-point university entrance exam, private language schools are expected to implement communicative language teaching. The teachers integrated the language skills of listening, speaking, reading, and writing employed communicative tasks including role-plays, information-gap tasks, opinion-gap tasks, etc. Teachers engaged learners in pair and group work, created opportunities for discussion of various topics, used prompt-based writing and speaking activities and game-based activities. Both teachers and learners were asked to complete consent forms.

\subsection{Procedure}

The data included 36 hours of audio recordings from six intact advanced adult EFL classes (six hours per class). The audio recordings were captured with a digital wireless voice recorder in each classroom. The teachers were asked to wear a wireless voice recorder with a clip-on microphone. The corpus used in this study was comprised of verbal teacher-learner interactions in one-on-one, small group, and whole-class. All six teachers used the same textbook (Speakout, Clare \& Wilson, 2016), syllabus, and supplementary materials. The teachers were asked to teach their normal classes and were not informed of the study's focus. Five hours of communicative-oriented interactions from each class were analyzed with a total of 30 hours of data after excluding the time allotted for roll call, greeting, and teaching isolated linguistic structures. 


\subsubsection{Coding FonF episodes}

Following other studies (Ellis et al., 2001), the unit of analysis was a focus-on-form episode (FFE) in this study. An FFE is defined as "the discourse from the point where the attention to linguistic form starts to the point where it ends, due to a change in topic back to message or sometimes another focus on form" (Ellis et al., 2001: 294). The beginning of an FFE is marked by a learner's non-target-like use of a form in reactive FonF, a learner's query about a form in student-initiated FonF, and the teacher's query or comment about a form in teacher-initiated FonF (Ellis et al., 2001). The end of an FFE is signaled by learner uptake, topic continuation by the teacher or learner, or another FFE (Ellis et al., 2001).

The researcher (the first coder) and a research assistant (the second coder) were involved in all coding procedures. The inter-coder reliabilities were achieved using Cohen's (1960) Kappa measure of agreement. Kappa values are reported and marked as $\kappa$ in the respective tables and appendices. Kappa values between $0.81-1.00$ are considered as high reliability (Cohen, 1960). The two coders independently listened to the audio recordings from one session of the class and identified FFEs. The intercoder reliability was found to be high, $\kappa=.92$. The coders established full reliability in all coding procedures by resolving any discrepancies in coding. The first coder listened to all audio recordings, identified all instances of FFEs, and transcribed them. Table 1 shows the linguistic foci of FFEs. Table 2 presents FFEs with different foci and characteristics. 
Table 1. Linguistic categories

\begin{tabular}{|c|c|c|}
\hline \multicolumn{2}{|l|}{ Linguistic focus } & Description $\quad$ Reliability $\kappa=.87$ \\
\hline A. Formulaic forms & 1. Collocation & $\begin{array}{l}\text { Linguistic features with formulaic } \\
\text { nature. A lexical collocation consists } \\
\text { of two content words (i.e., adjective, } \\
\text { adverb, noun, or verb) that both } \\
\text { contribute almost equally to its entire } \\
\text { meaning. } \\
\text { A grammatical collocation consists } \\
\text { of a dominant content word (i.e., a } \\
\text { noun, a verb, or an adjective) and a } \\
\text { subordinate grammatical structure (i.e., } \\
\text { a preposition, an infinitive, or a clause) } \\
\text { (Benson, Benson, \& Ilson, 2010). }\end{array}$ \\
\hline & $\begin{array}{l}\text { 2. Lexical } \\
\text { bundle }\end{array}$ & $\begin{array}{l}\text { Lexical bundles are recurrent } \\
\text { expressions that "commonly go together } \\
\text { in natural discourse" (Biber, Johansson, } \\
\text { Leech, Conrad, \& Finegan, 1999: 990). }\end{array}$ \\
\hline & 3. Idiom & $\begin{array}{l}\text { Idioms are "opaque invariant word } \\
\text { combinations" (Warren, 2005: 35). }\end{array}$ \\
\hline & 4. Compound & $\begin{array}{l}\text { Compounding is the creation of a word } \\
\text { with a specific meaning by blending } \\
\text { two existing words (Wood, 2020). }\end{array}$ \\
\hline \multirow[t]{4}{*}{ B. Non-formulaic forms } & 1. Grammar & $\begin{array}{l}\text { Linguistic features with non-formulaic } \\
\text { nature. Subject-verb agreement, tense, } \\
\text { plurals, word order, question formation, } \\
\text { negation, determiners, pronouns, } \\
\text { prepositions, plural, verb morphology, } \\
\text { sentence construction, etc }\end{array}$ \\
\hline & 2. Pronunciation & $\begin{array}{l}\text { Segmental and supra-segmental aspects } \\
\text { of the phonological system that are } \\
\text { not related to bound grammatical } \\
\text { morphemes. } \\
\text { Pronunciation of words. }\end{array}$ \\
\hline & 3. Vocabulary & Meaning of single-word items. \\
\hline & 4. Spelling & $\begin{array}{l}\text { The orthographic form of words (Ellis } \\
\text { et al., 2001). }\end{array}$ \\
\hline
\end{tabular}


Table 2. Instances of FFEs with different characteristics

\begin{tabular}{|c|c|c|}
\hline Example 1: Episode with formulaic focus & Characteristics & Category \\
\hline $1 \mathrm{~S}$ Rush hour means? & Type & Student-initiated \\
\hline $\begin{array}{l}2 \mathrm{~T} \text { The busy hour (..) I mean (.) for example, } \\
\text { from } 5: 30 \text { to } 6 \text { in the evening (.) }\end{array}$ & $\begin{array}{l}\text { Linguistic focus } \\
\text { Source }\end{array}$ & $\begin{array}{l}\text { Lexical collocation } \\
\text { Message }\end{array}$ \\
\hline $3 \mathrm{~S}$ Yes! & Complexity & Complex \\
\hline $\begin{array}{l}4 \text { T In Ramadan (.) it is the rush hour (.) } \\
\text { people are rushing home to break their } \\
\text { fast as quickly as possible. ha! }\end{array}$ & $\begin{array}{l}\text { Directness } \\
\text { Emphasis } \\
\text { Timing }\end{array}$ & $\begin{array}{l}\text { Direct } \\
\text { Heavy } \\
\text { Immediate }\end{array}$ \\
\hline $5 \mathrm{~S}$ Yeah (.) I drive home in the rush hour. & $\begin{array}{l}\text { Response } \\
\text { Uptake }\end{array}$ & $\begin{array}{l}\text { Provide } \\
\text { Uptake, successful }\end{array}$ \\
\hline Example 2: Episode with formulaic focus & Characteristics & Category \\
\hline $1 \mathrm{~S}$ On other words (.) & Type & Reactive \\
\hline 2 T IN other words (.) & Linguistic focus & Lexical bundle \\
\hline $\begin{array}{l}3 \mathrm{~S} \text { Ahh (.) sorry (.) in other words (.) some } \\
\text { people don't care about the dangers of } \\
\text { smoking }\end{array}$ & $\begin{array}{l}\text { Source } \\
\text { Complexity } \\
\text { Directness } \\
\text { Emphasis } \\
\text { Timing } \\
\text { Response } \\
\text { Uptake } \\
\end{array}$ & $\begin{array}{l}\text { Code } \\
\text { Simple } \\
\text { Direct } \\
\text { Light } \\
\text { Immediate } \\
\text { Provide } \\
\text { Uptake, successful }\end{array}$ \\
\hline Example 3: Episode with formulaic focus & Characteristics & Category \\
\hline $\begin{array}{l}1 \mathrm{~T} \text { What does tie the knot mean? initiated } \\
\text { any ideas? }\end{array}$ & $\begin{array}{l}\text { Type } \\
\text { Linguistic focus }\end{array}$ & $\begin{array}{l}\text { Teacher-initiated } \\
\text { Idiom }\end{array}$ \\
\hline $\begin{array}{l}2 \text { S ندز هرگ (the equivalent of to tie in Persian) } \\
\text { /'gereh zædæn/ }\end{array}$ & $\begin{array}{l}\text { Source } \\
\text { Complexity }\end{array}$ & $\begin{array}{l}\text { Message } \\
\text { Complex }\end{array}$ \\
\hline 3Ss@ & Directness & Direct \\
\hline $4 \mathrm{~T}$ NO (.) It's an expression. & Emphasis & Heavy \\
\hline $\begin{array}{l}5 \text { T For example (.) my fiancé and I are going } \\
\text { to tie the knot (..) means? } \\
\text { We'll get married. To tie the knot (.) } \\
\text { means to get married. } \\
\text { OK, back to the reading ... }\end{array}$ & $\begin{array}{l}\text { Timing } \\
\text { Response } \\
\text { Uptake }\end{array}$ & $\begin{array}{l}\text { Immediate } \\
\text { Provide } \\
\text { No opportunity }\end{array}$ \\
\hline
\end{tabular}




\begin{tabular}{lll}
\hline Example 4: Episode with formulaic focus & Characteristics & Category \\
\hline 1 S Teenagers today (.) don't know how to & Type & Reactive \\
deal for their problems. & Linguistic focus & Grammatical \\
& & collocation \\
2 T deal for or deal WITH? & Source & Code \\
3 S Deal with. & Complexity & Simple \\
4 T Right! & Directness & Indirect \\
5 S Thanks (.) dealing with the ... & Emphasis & Light \\
& Timing & Immediate \\
& Response & Elicit \\
& Uptake & Uptake, successful \\
\hline Example 5: Episode with formulaic focus & Characteristics & Category \\
\hline 1S I want to travel to other countries (..) & Type & Student-initiated \\
What we say? What hiking? & Linguistic focus & Compound \\
2 T Hitchhiking (.) you mean? & Source & Message \\
3 Like you don't have a car, but you want & Complexity & Complex \\
to travel to another city, and you thumb & Directness & Direct \\
(teacher demonstrating the thumb signal for & Emphasis & Heavy \\
hitchhiking). Well (.) class is over. & Timing & Immediate \\
& Response & Provide \\
& Uptake & No opportunity \\
\hline Example 6: Episode with non-formulaic & Characteristics & Category \\
focus & & \\
\hline 1 S She influence my entire life & Type & Reactive \\
2 T She influence my entire life & Linguistic focus & Grammar \\
INFLUENCE? & Source & Code \\
3 S Yeah. & Complexity & Simple \\
& Directness & Direct \\
& Emphasis & Light \\
& Timing & Delayed \\
& Response & Elicit \\
& Uptake & Uptake, successful \\
\hline
\end{tabular}




\begin{tabular}{|c|c|c|}
\hline $\begin{array}{l}\text { Example 7: Episode with non-formulaic } \\
\text { focus }\end{array}$ & Characteristics & Category \\
\hline $1 \mathrm{~S}$ How do you pronounce this? & Type & Student-initiated \\
\hline $2 \mathrm{~T} /$ nu:'mouniə/ & $\begin{array}{l}\text { Linguistic focus } \\
\text { Source } \\
\text { Complexity } \\
\text { Directness } \\
\text { Emphasis } \\
\text { Timing } \\
\text { Response } \\
\text { Uptake }\end{array}$ & $\begin{array}{l}\text { Pronunciation } \\
\text { Code } \\
\text { Simple } \\
\text { Direct } \\
\text { Light } \\
\text { Immediate } \\
\text { Elicit } \\
\text { No uptake }\end{array}$ \\
\hline $\begin{array}{l}\text { Example 8: Episode with non-formulaic } \\
\text { focus }\end{array}$ & Characteristics & Category \\
\hline 1 T Did you get the meaning of sabotage? & Type & Teacher-initiated \\
\hline 2 Ss $(\ldots)$. & Linguistic focus & Vocabulary \\
\hline 3 T To destroy. To damage. & $\begin{array}{l}\text { Source } \\
\text { Complexity } \\
\text { Directness } \\
\text { Emphasis } \\
\text { Timing } \\
\text { Response } \\
\text { Uptake }\end{array}$ & $\begin{array}{l}\text { Message } \\
\text { Simple } \\
\text { Direct } \\
\text { Light } \\
\text { Immediate } \\
\text { Provide } \\
\text { No uptake }\end{array}$ \\
\hline
\end{tabular}

\subsubsection{Coding foci of FFEs}

Chomsky (1965) posited that depending on the context, the word sequence "decide on a boat" in the sense of "decide while on a boat" is a loose non-formulaic construction. In contrast, the same word sequence in the sense of "decide what boat to choose" is a close formulaic construction. The dual-nature view of language is substantiated by Sinclair's (1991) open-choice principle (non-formulaic forms) and the idiom principle (formulaic forms).

Formulaic constructions (e.g., on the other hand) are distinct from non-formulaic constructions (e.g., on the other foot) in that in the former, at least one constituent cannot be replaced by a synonymous word or phrase without changing function, meaning, or idiomaticity, which is known as restricted exchangeability (Erman \& Warren, 2000). Formulaic forms are characterized as "any sequence of two or more words that are perceived to be more constrained than usual in their co-occurrence" (Hudson \& Wiktorsson, 2009: 81). Non-formulaic forms refer to "elements used in 
their literal senses and freely substitutable" (Howarth, 1998: 28). Non-formulaic forms are generated by syntactic analysis in which "the only restraint is grammaticalness" (Sinclair, 1991: 109).

Previous studies made a distinction between non-formulaic (drop the beans) and formulaic (spill the beans) language, albeit for different research purposes (e.g., Gholami, 2021a, 2021b, 2021c; Gholami, Karimi, \& Atai, 2017). For the purpose of this study, non-formulaic forms were differentiated from formulaic forms. Formulaic forms were analyzed as a separate category in this study as FSs "are nevertheless significant enough to be the focus of research, and a theoretical category meriting particular attention" (Buerki, 2016: 15). FSs were not examined in terms of their individual components as they "constitute single choices, even though they might appear to be analyzable into segments" (Sinclair, 1991: 110). Similarly, FSs were not subsumed under the category of vocabulary because they "are not the products of general rules applying to words, and nor do they, in general, behave like single words" (Buerki, 2016: 16).

The two coders marked FFEs for formulaic and non-formulaic foci. Following Wood's (2020) suggestion to rely on native-speaker intuition, the second coder, a native speaker of American English (a Ph.D. in applied linguistics), was involved in identifying FFEs with formulaic foci. The coders read Wood's (2020) summary of checklists employed for the identification of FSs. Based on the speaker-external view of formulaicity, FSs are demarcated from non-formulaic forms in terms of their formal properties, that is, semantic irregularity (kick the bucket), syntactic idiosyncrasy (by and large), pragmatic functions (what's up?), or frequency of co-occurrence (rock and roll) (Myles \& Cordier, 2017). The coders used Wray and Namba's (2003) checklist (Appendix A) as the main checklist for judging formulaic vs. non-formulaic foci of FFEs. Their checklist is comprehensive with 11 criteria and guidelines on how to employ different criteria for various datasets involving error-free, error in the form, and error in usage (See Wray \& Namba, 2003, for detailed guidelines).

After dividing FFEs into episodes with formulaic and non-formulaic foci, they were coded for categories of the (non)formulaic forms presented in Table 1. Zhao \& Bitchener (2007: 438) provide sub-categories of non-formulaic forms. In FFEs with formulaic foci, FSs are focused on to address: (a) form, meaning, or usage; (b) lexical selection; and/or (c) lexical formation (Millar, 2011) (Appendix B). In the FS "a piece of cake" (easy to do), the figurative sense is lost by lexical misselection "a piece of pancake" or lexical misformation "the piece of cake" (Xu, 2015). Nesselhauf (2005) delimited formulaic errors (i.e., those stemming directly from the phraseological status of FSs) from non-formulaic errors (i.e., those about the syntactic rules governing non-formulaic constructions). For instance, in the word sequence "she make judgments," if the subjectverb agreement was targeted, the FFE was marked as non-formulaic. Nevertheless, 
if lexical selection (pass judgment) or lexical formation (judgment is never pluralized because of the formulaic status) were targeted, the FFE was marked as formulaic.

\subsubsection{Coding categories of FSs}

Collocations are distinct from non-formulaic combinations due to the arbitrary restriction on combinability (Nesselhauf, 2005). For instance, the word string "kick the stone" is a free combination as all its components could be replaced by other words (kick the ball). However, in the word string "kick a habit," the base (habit) in the sense used in the collocational unit could be combined with other linguistic items, but the collocator (kick) in the sense used in the collocational unit is arbitrarily restricted to certain elements (break a habit) (Nesselhauf, 2005). Two major sub-categories of collocations include lexical collocations (brain drain) and grammatical collocations (on purpose) (Xu, 2015) that were coded using the schemes presented in Appendices C and D, respectively. Following Nesselhauf (2005), the identified collocations were crosschecked with The BBI Combinatory Dictionary of English (2010). Lexical bundles (the extent to which) were coded using Simpson-Vlach \& Ellis's (2010) Academic Formulas List (AFL), which provides lists of lexical bundles frequently found in English written and spoken discourses (See Appendix E). Idioms were identified using the Oxford Dictionary of English Idioms (2010) and The Oxford Dictionary of Idioms (2005). Compounds were coded using the coding scheme presented in Appendix F.

\subsubsection{Coding uptake}

As Figure 1 illustrates, FFEs were coded for: (a) no opportunity for uptake when a learner has no chance to react to target form because the teacher or another learner immediately continues a topic; (b) no uptake when the learner does not react to target form despite having a chance to react; (c) uptake when the learner responds to target form triggering the FFE. The inter-coder reliability for uptake was found to be high, $\kappa$ $=0.85$. FFEs with uptake were further coded for (d) successful uptake when the learner successfully incorporates target form into production by rephrasing, correcting the error, or using the target form correctly in an example; (e) unsuccessful uptake when the learner's response to the target form requires further correction. Unsuccessful uptake involves acknowledgment when learner acknowledges the recognition of target form by uttering thanks, yeah, etc.; modified when learner modifies the error incorrectly or partially correctly; and unmodified when the learner does not modify the error, expresses difficulty understanding the target form, or circumvents the use of target form. The inter-coder reliability for successful uptake was found to be high, $\kappa=0.82$. Learners' errors with forms that were not targeted in an FFE were disregarded. 
Figure 1. Coding scheme of uptake (adopted from Egi, 2010).

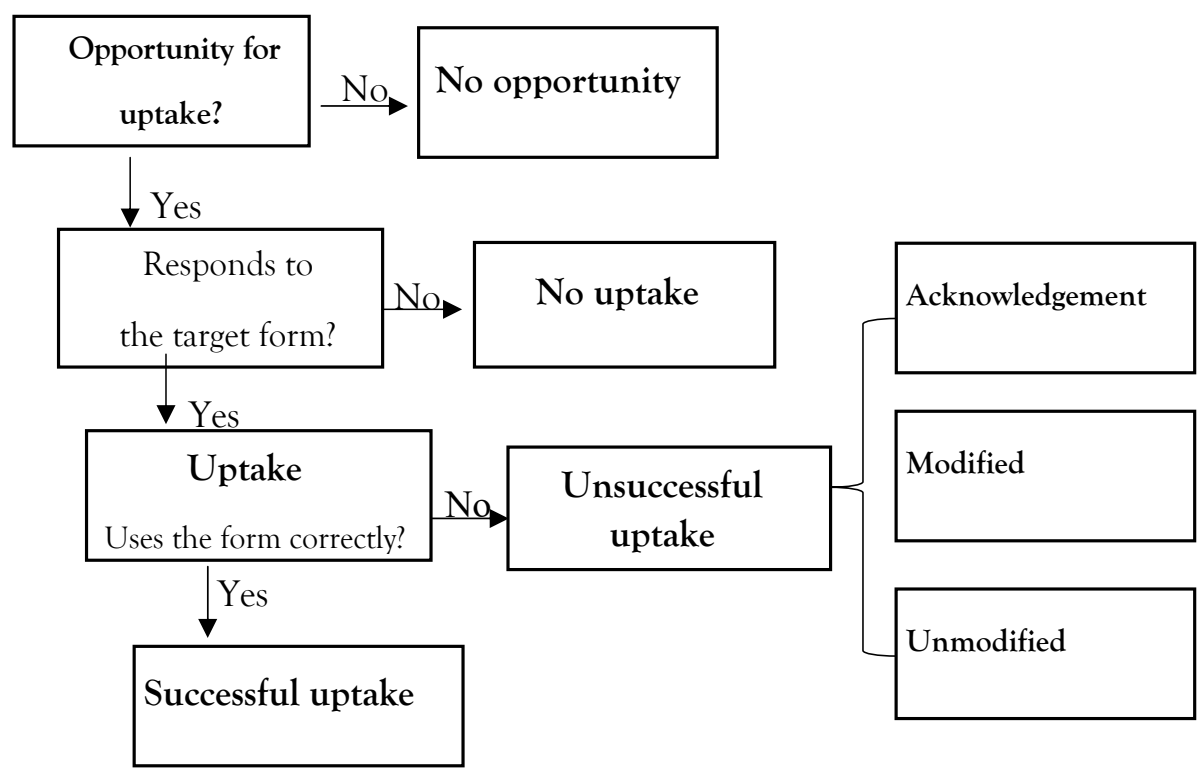

\subsubsection{Coding characteristics of FFEs}

All FFEs were further coded for the characteristics presented in Table 3. Table 2 presents instances of FFEs with different characteristics. 
Table 3. Characteristics of FFEs (adopted from Loewen, 2005: 376)

\begin{tabular}{|c|c|c|c|}
\hline Characteristic & Definition & Categories & $\mathrm{k}=$ Reliability \\
\hline Type & Instigation & $\begin{array}{l}\text { Reactive FFE: It "arises when learners produce } \\
\text { an utterance containing an actual or perceived } \\
\text { error, which is then addressed usually by the } \\
\text { teacher but sometimes by another learner. } \\
\text { Thus, it supplies learners with negative } \\
\text { evidence" (Ellis et al., 2001: } 413 \text { ). } \\
\text { Preemptive FFE: It involves a learner or the } \\
\text { teacher "initiating attention to form even } \\
\text { though no actual problem in production has } \\
\text { arisen" by raising a query (Ellis et al., 2001: 414). }\end{array}$ & $k=0.855$ \\
\hline Source & $\begin{array}{l}\text { Reason for } \\
\text { instigation }\end{array}$ & $\begin{array}{l}\text { Code: An FFE involves the inaccurate use of a } \\
\text { form with no apparent miscommunication (i.e., } \\
\text { negotiation of the form). } \\
\text { Message: An FFE involves problems with } \\
\text { understanding meaning (i.e., negotiation of the } \\
\text { meaning). }\end{array}$ & $k=0.857$ \\
\hline Complexity & Length & $\begin{array}{l}\text { Simple: An FFE involves a single exchange } \\
\text { to resolve the linguistic problem. } \\
\text { Complex: An FFE involves two or more } \\
\text { exchanges to resolve the linguistic problem }\end{array}$ & $k=0.789$ \\
\hline Directness & Explicitness & $\begin{array}{l}\text { Indirect: Attention to form is implicit. } \\
\text { Direct: Attention to form is explicit. }\end{array}$ & $k=0.832$ \\
\hline Emphasis & $\begin{array}{l}\text { Complexity } \\
+ \text { directness }\end{array}$ & $\begin{array}{l}\text { Light: An FFE is indirect and simple } \\
\text { Heavy: An FFE is direct and/or complex }\end{array}$ & $k=0.790$ \\
\hline Timing & $\begin{array}{l}\text { Response } \\
\text { timing }\end{array}$ & $\begin{array}{l}\text { Immediate: An FFE is immediately provided } \\
\text { Delayed: An FFEs is provided with some delay. }\end{array}$ & $\mathrm{k}=0.986$ \\
\hline Response & $\begin{array}{l}\text { Type of } \\
\text { feedback }\end{array}$ & $\begin{array}{l}\text { Provide: The teacher provides learners with } \\
\text { target form through recasts or explicit } \\
\text { corrections. } \\
\text { Elicit: The teacher elicits target form from } \\
\text { learners through clarification requests, } \\
\text { repetitions, metalinguistic clues and elicitations }\end{array}$ & $\mathrm{k}=0.809$ \\
\hline Uptake & $\begin{array}{l}\text { Student } \\
\text { response to } \\
\text { feedback }\end{array}$ & $\begin{array}{l}\text { Uptake: The learner responds to the target form } \\
\text { No uptake: The learner does not respond to } \\
\text { target form. }\end{array}$ & $\mathrm{k}=0.991$ \\
\hline $\begin{array}{l}\text { Successful } \\
\text { uptake }\end{array}$ & $\begin{array}{l}\text { Quality } \\
\text { of student } \\
\text { response }\end{array}$ & $\begin{array}{l}\text { Successful uptake: The learner incorporates } \\
\text { the target form into production. } \\
\text { Unsuccessful uptake: The learner does not } \\
\text { successfully incorporate target form into } \\
\text { production. }\end{array}$ & $\mathrm{k}=0.889$ \\
\hline
\end{tabular}

Note. $k$ refers to the inter-coder reliability. 


\section{Results}

A total of 1,425 FFEs were identified in 30 hours of teacher-learner interactions. The focus of 551 episodes was formulaic, and 874 FFEs focused on non-formulaic forms. Therefore, learners' attention was shifted to non-formulaic forms (61\%) more often than FSs (39\%). Table 4 shows (successful) uptake rate in FFEs with (non)formulaic foci. Instances of FFEs where there was no opportunity for learners to produce uptake were excluded $(n=63)$. Uptake occurred in a total of 746 FFEs comprising more than half of the total episodes (55\%). Chi-square tests were conducted to investigate the statistical associations between (non)formulaic foci of FFEs and (successful) uptake rate. The inferential statistics were calculated using Statistical Package for the Social Sciences (SPSS) 25.0. An alpha level of $p<0.05$ was set for all chi-square tests. The association between the (non)formulaic foci of FFEs and uptake rate was found to be significant, $\chi^{2}(1,1362)=131.746, p=0.000$. The effect size was medium, $w=0.3$. Therefore, learners produced uptake more often in FFEs with formulaic foci (52\%) than non-formulaic foci (48\%). The association between (non)formulaic foci of FFEs and successful uptake rate was found to be significant, $\chi^{2}(1,746)=100.684, p=0.000$. The effect size was medium, $w=0.4$. Hence, learners produced successful uptake more often in FFEs with formulaic foci (66\%) than non-formulaic foci (34\%).

Table 4. (Successful) uptake rate according to (non) formulaic foci

\begin{tabular}{lcccccccc}
\hline & \multicolumn{2}{c}{ No uptake } & \multicolumn{2}{c}{ Uptake } & \multicolumn{2}{c}{$\begin{array}{c}\text { Successful } \\
\text { uptake }\end{array}$} & \multicolumn{2}{c}{$\begin{array}{c}\text { Unsuccessful } \\
\text { uptake }\end{array}$} \\
\hline & No. & $\%$ & No. & $\%$ & No. & $\%$ & No. & $\%$ \\
\hline Formulaic & 134 & 22 & 389 & 52 & 314 & 66 & 75 & 28 \\
Non-formulaic & 482 & 78 & 357 & 48 & 162 & 34 & 195 & 72 \\
Total & 616 & 45 & 746 & 55 & 476 & 64 & 270 & 36 \\
\hline
\end{tabular}

Note. The percentages are rounded off.

Binary logistic regression analyses were performed to investigate the characteristics that mediate the occurrence of (successful) uptake in FFEs with formulaic vs. nonformulaic foci. The logistic regression analysis results are reported in terms of odds ratio and 95\% confidence interval for each independent variable (Hosmer \& Lemeshow, 2000). The logistic regression analysis for uptake in FFEs with formulaic foci revealed an overall percentage accuracy of $68.6 \%$. The variables of type, source, complexity, emphasis, timing, and response were found to be significant predictors of uptake in FFEs with formulaic foci. As Table 5 shows, the odds ratio for the type of incidental FonF was found to be 3.841, meaning that preemptive FFEs targeting FSs were roughly 
four times more likely to lead to uptake than reactive episodes. The odds ratio for the source of FonF was found to be 14.889, indicating that message-related FFEs with formulaic foci were approximately fifteen times more likely to contain uptake than code-related episodes. Complexity has an odds ratio of 6.099, indicating that FFEs with formulaic foci involving many uptake moves were six times more likely to result in uptake than simple episodes. Emphasis has an odds ratio of 4.943, meaning that FFEs with formulaic foci involving several direct uptake moves stand roughly five times more chance of culminating in uptake than simple indirect episodes. The odds ratio for timing was 0.206 , meaning that delayed FFEs with formulaic foci were one-fifth as likely to contain uptake as immediate episodes. The odds ratio for the variable of response was found to be 4.948, meaning that eliciting target forms from learners was roughly five times more likely to lead to an uptake in FFEs with formulaic foci than providing learners with correct forms.

Table 5. Logistic regression for uptake in formulaic FFEs

\begin{tabular}{lccccc}
\hline & & & \multicolumn{2}{c}{$95 \%$ confidence intervals } & \\
\cline { 5 - 6 } Variable & S.E. & Odds ratio & Lower & Upper & Significance \\
\hline Type & .235 & 3.841 & 2.422 & 6.09 & .000 \\
Source & .286 & 14.889 & 8.507 & 26.058 & .000 \\
Complexity & .247 & 6.099 & 3.757 & 9.900 & .000 \\
Emphasis & .239 & 4.943 & 3.097 & 7.892 & .000 \\
Timing & .238 & 206 & 129 & 328 & .000 \\
Response & .236 & 4.948 & 3.117 & 7.854 & .000 \\
\hline
\end{tabular}

The second logistic regression analysis conducted for successful uptake in FFEs with formulaic foci revealed an overall percentage accuracy of $74.1 \%$. The variables of type, source, complexity, emphasis, timing, and response were found to be significant predictors of successful uptake in FFEs with formulaic foci. As Table 6 shows, preemptive FFEs with formulaic focus were two and a half times (odds ratio $=2.547$ ) more likely to lead to successful uptake than reactive episodes. Message-related FFEs with formulaic foci were seven times (odds ratio $=7.386$ ) more likely to culminate in successful uptake than code-related ones. The odds ratio for complexity was found to be 2.124, meaning that complex FFEs with formulaic foci were twice more likely to result in successful uptake than simple ones. Heavy emphasis (odds ratio $=4.545$ ) on FSs in FFEs with formulaic foci involving several direct uptake moves was four and a half times more likely to contain successful uptake than light emphasis involving simple indirect uptake moves. Delayed FFEs with formulaic foci (odds ratio $=0.196$ ) were 
roughly one-fifth as likely to culminate in successful uptake as immediate episodes. Finally, eliciting target forms from learners was almost five times (odds ratio $=4.946$ ) more likely to lead to successful uptake in FFEs with formulaic foci than providing learners with correct forms.

Table 6. Logistic regression for successful uptake in formulaic FFEs

\begin{tabular}{lccccc}
\hline & & & \multicolumn{2}{c}{$95 \%$ confidence intervals } & \\
\cline { 4 - 5 } Variable & S.E. & Odds ratio & Lower & Upper & Significance \\
\hline Type & .286 & 2.547 & 1.455 & 4.461 & .001 \\
Source & .313 & 7.386 & 4.002 & 13.632 & .000 \\
Complexity & .288 & 2.124 & 1.208 & 3.736 & 009 \\
Emphasis & .296 & 4.545 & 2.544 & 8.120 & .000 \\
Timing & .299 & 196 & 109 & 353 & .000 \\
Response & .300 & 4.946 & 2.749 & 8.899 & .000 \\
\hline
\end{tabular}

The logistic regression analysis for uptake in FFEs with non-formulaic foci showed an overall percentage accuracy of $61.5 \%$. The variables of type, source, complexity, directness, emphasis, timing, and response were found to be significant predictors of uptake in FFEs with non-formulaic foci. As Table 7 presents, the odds ratio of type was 0.259 , meaning that preemptive FFEs with non-formulaic foci were one-third as likely to contain uptake as reactive episodes. The source's odds ratio was 0.277 , meaning that message-related FFEs with non-formulaic foci were one-third as likely to contain uptake as code-related episodes. The odds ratio of complexity was 2.049 , indicating that complex FFEs with non-formulaic foci were twice more likely to end with uptake than simple episodes. Directness has an odds ratio of 0.304, meaning that indirect episodes with non-formulaic foci were one-third as likely to culminate in successful uptake as direct episodes. The odds ratio of emphasis was 2.049, indicating that FFEs with non-formulaic foci involving heavy emphasis were twice more likely to result in uptake than episodes with light emphasis. The odds ratio for timing was found to be 4.628 , indicating that delayed FFEs with non-formulaic foci were roughly five times more likely to end with uptake than immediate episodes. The response has an odds ratio of 0.476 , indicating that eliciting target forms from learners in FFEs with nonformulaic foci was roughly one-fifth as likely to contain uptake as providing learners with target form. 
Table 7. Logistic regression for uptake in non-formulaic FFEs

\begin{tabular}{|c|c|c|c|c|c|}
\hline \multirow[b]{2}{*}{ Variable } & \multirow[b]{2}{*}{ S.E. } & \multirow[b]{2}{*}{ Odds ratio } & \multicolumn{2}{|c|}{ 95\% confidence intervals } & \multirow[b]{2}{*}{ Significance } \\
\hline & & & Lower & Upper & \\
\hline Type & .150 & .259 & .199 & .358 & .000 \\
\hline Source & .153 & .277 & .205 & .374 & .000 \\
\hline Complexity & .155 & 2.049 & 1.513 & 2.774 & .000 \\
\hline Directness & .152 & .304 & .226 & .409 & .000 \\
\hline Emphasis & .155 & 2.049 & 1.513 & 2.774 & .000 \\
\hline Timing & .158 & 4.628 & 3.396 & 6.306 & .000 \\
\hline Response & .148 & .476 & .357 & .637 & .000 \\
\hline
\end{tabular}

The logistic regression analysis for successful uptake in FFEs with non-formulaic foci showed an overall percentage accuracy of $54 \%$. The variables of type, source, complexity, directness, emphasis, timing, and response were found to be significant predictors of successful uptake in FFEs with non-formulaic focus. As presented in Table 8, preemptive FFEs with non-formulaic foci were one-third (odds ratio $=0.265$ ) as likely to contain successful uptake as reactive ones. Message-related FFEs with non-formulaic foci were roughly one-fourth (odds ratio $=0.396$ ) as likely to result in successful uptake as code-related episodes. Complex FFEs with non-formulaic foci were three times (odds ratio $=3.236$ ) more likely to end with successful uptake than simple episodes. Indirect FFEs with non-formulaic foci were one-third (odds ratio $=0.347$ ) as likely to contain successful uptake as direct episodes. FFEs with non-formulaic foci involving several direct moves were three times (odds ratio $=3.152$ ) more likely to lead to successful uptake than those with light focus. Delayed FFEs with non-formulaic foci were five times (odds ratio $=5.188$ ) more likely to result in successful uptake than immediate ones. Finally, eliciting target forms from learners in FFEs with nonformulaic foci was one-third (odds ratio $=0.297$ ) as likely to culminate in successful uptake than providing learners with target forms. Therefore, the findings of logistic regression analyses showed that FonF characteristics predicting learners' production of (successful) uptake were different for formulaic vs. non-formulaic forms targeted in FFEs. 
Table 8. Logistic regression for successful uptake in non-formulaic FFEs

\begin{tabular}{lccccc}
\hline & & & \multicolumn{3}{c}{$95 \%$ confidence intervals } \\
\cline { 5 - 6 } Variable & S.E. & Odds ratio & Lower & Upper & Significance \\
\hline Type & .253 & .265 & .195 & .354 & .000 \\
Source & .236 & .396 & .250 & .629 & .000 \\
Complexity & .239 & 3.236 & 2.028 & 5.165 & .000 \\
Directness & .237 & .347 & .218 & .552 & .000 \\
Emphasis & .238 & 3.152 & 1.977 & 5.927 & .000 \\
Timing & .250 & 5.188 & 3.181 & 8.461 & .000 \\
Response & .240 & .297 & .185 & .474 & .000 \\
\hline
\end{tabular}

\section{Discussion}

\subsection{Uptake of (non)formulaic forms}

This study examined the extent to which learners produced (successful) uptake following FSs targeted in FEEs compared to non-formulaic forms targeted in FFEs. Also, incidental FonF characteristics that mediated learners' production of (successful) uptake in FFEs following target FSs were compared with target non-formulaic forms. The findings indicated that non-formulaic forms $(61 \%)$ were more frequently focused on than formulaic forms (39\%) in the observed classrooms. However, learners produced uptake (52\%) and successful uptake (66\%) more often when FSs were targeted in FFEs than non-formulaic forms (uptake $=48 \%$, successful uptake $=34 \%$ ). In line with this study's findings, Lyster (2001) found that learners generated (successful) uptake more often following lexical items than grammar and pronunciation. Learners' production of successful uptake following FonF has been associated with their subsequent language learning (e.g., Egi, 2010; Ellis et al., 2001; Loewen, 2004; Lyster, 2001). Lyster (2001) concluded that FonF directed at lexically-oriented items results in a higher successful uptake rate and subsequently effective learning than FonF targeting morphosyntax. 
Learners' higher production of (successful) uptake following FSs in FFEs than non-formulaic forms as found in this study is attributed to the greater saliency, communicative value, and noticeability of FSs. Wulff (2019) posits that vocabulary items are more salient than morphosyntax, and FSs are even more salient than singleword vocabulary items. In addition, FSs perform different discourse functions and play a key role in communicating meaning (Wullf, 2019). In this regard, Kecskes (2016) notes that FSs are "not only salient but also functionally significant" (p. 10). Learners' production of successful uptake is deemed an indicator of noticing target forms (Egi, 2010). Therefore, the higher proportion of successful uptake following target FSs as found in this study suggests the greater noticeability of FSs than non-formulaic forms. Li \& Vuono (2019) maintain that the nature of linguistic forms influences the degree of noticeability of forms by learners and their subsequent production of successful uptake. This study's findings support the conviction that forms with formulaic nature are more salient, noticeable, and communicatively more important than forms involving grammar, pronunciation, and single-word vocabulary as indicated by markedly higher (successful) uptake rate following FSs.

In this study, learners' attention was raised to non-formulaic forms (61\%) more often than FSs (39\%) in FFEs. Nonetheless, learners tended to produce more successful uptake following target FSs (66\%) than no-formulaic forms (34\%). While not questioning targeting non-formulaic forms, this study suggests that learners' attention be drawn to formulaic aspects of language more frequently through FFEs to achieve a balanced representation of formulaic and non-formulaic aspects of language in incidental FonF. Learners' production of successful uptake in incidental FonF provides them with the opportunity "to notice linguistic items and structures at the very moment they are most needed for communication" (Loewen \& Sato, 2019: 10), leading to restructuring interlanguage toward target models (Panova \& Lyster, 2002). Therefore, another line of this study examined incidental FonF characteristics that mediate learners' production of (successful) uptake following target FSs compared to non-formulaic forms in FFEs.

\subsection{FonF characteristics predicting learner uptake}

This study's findings showed that FonF characteristics that predicted learners' production of (successful) uptake were different for formulaic forms vs. non-formulaic forms targeted in FFEs. To the best of the researcher's knowledge, to date, no studies have examined incidental FonF characteristics that influence learners' production of (successful) uptake following FSs to make comparisons with the findings of this study. In this study, preemptive FonF was a strong predictor of learners' production of (successful) uptake when FSs were targeted in FFEs. In contrast, reactive FonF was 
a strong predictor of learners' production of (successful) uptake when non-formulaic forms were targeted in FFEs.

A partial explanation for differences in these findings might lie in the formulaic vs. non-formulaic nature of target forms. Ellis et al. (2001) differentiate between actual and perceived linguistic gaps in learners' knowledge. Student-initiated preemptive FonF, where learners take responsibility for their own learning by raising queries, has the potential to address learners' actual linguistic gaps (Ellis et al., 2001). However, teacher-initiated reactive FonF, where teachers provide corrective feedback to learners' errors, may address their perceived errors (Ellis et al., 2001). The learners in this study were advanced adult learners taking tuition-based classes, so they might have taken responsibility for addressing their problems with FSs by using student-initiated preemptive FonF and subsequently producing (successful) uptake to communicate their meaning. In this regard, Loewen (2004) notes that instructional context and learners' proficiency level, among other factors, influence learners' use of studentinitiated FonF and the production of successful uptake.

On the other hand, learners' errors with non-formulaic forms involving grammar at advanced level classes might have arisen due to the spontaneous language use as advanced learners are expected to have already developed substantial knowledge of grammar and vocabulary (Meunier, 2012), which could result in teachers' using reactive FonF to correct learners' errors, leading to learners' higher successful uptake of nonformulaic forms following reactive FonF. Therefore, this study's findings suggest that to increase learners' production of successful uptake in FFEs, teachers should use reactive FonF to address non-formulaic forms and provide opportunities for learners to take the initiative and preemptively address FSs through preemptive FonF.

Another variable predicting learners' successful uptake in FFEs with formulaic vs. non-formulaic foci was the type of corrective feedback in FonF. The findings showed that eliciting target FSs from learners through output-prompting feedback types strongly predicted learners' production of (successful) uptake in FFEs. However, providing learners with target non-formulaic forms through input-providing feedback types strongly predicted learners' production of (successful) uptake in FFEs. Feedback strategies are categorized into input-providing (i.e., using recasts and explicit corrections) and output-prompting types (i.e., eliciting target forms, making clarification requests, repeating errors, and providing metalinguistic clues) (Li \& Vuono, 2019).

The findings of this study suggest that the nature of forms in terms of formulaic vs. non-formulaic mediate the effectiveness of different corrective feedback types as measured by successful uptake rate. Likewise, the findings of Brown's (2016) metaanalysis demonstrated that the nature of linguistic target moderates the efficacy of 
corrective feedback. Similarly, Lyster \& Mori's (2006) counterbalance hypothesis indicates that the provision of corrective feedback should vary depending on instruction's focus on morphosyntax or lexical items. Additionally, the nature of linguistic target in terms of whether it entails item learning (FSs) or system learning (grammar) is a factor that "can determine the relative effect of different strategies on noticing, uptake with repair, and acquisition" (Ellis, 2017: 11). Ellis (2017) argues that teachers should not select corrective feedback types randomly "but should apply them systematically" (p. 12). Hence, to promote learners' production of successful uptake following FSs, this study's findings suggest using output-prompting corrective feedback types. However, to promote learners' production of successful uptake following nonformulaic forms, this study's findings suggest using input-providing corrective feedback types.

Source of FonF was another variable mediating learners' provision of (successful) uptake following FSs vs. non-formulaic forms in FFEs. Learners produced more (successful) uptake following FSs when FFEs involved message conveyance. However, learners produced more (successful) uptake following non-formulaic forms when FFEs involved the accuracy of form. These differences in findings could be explained by the distinction between the negotiation of form versus negotiation of meaning, as Ellis et al. (2001) suggested. Ellis et al. (2001) argue that forms pertaining to phonology and morphosyntax mainly require negotiation of form to enhance linguistic accuracy despite the lack of any communication breakdown. On the other hand, lexicallyoriented forms, including FSs require negotiation of meaning to resolve meaning and communication problems (Ellis et al., 2001). Hence, FSs lend themselves more to the negotiation of meaning, resulting in a higher (successful) uptake rate. In contrast, nonformulaic forms lend themselves more to the negotiation of form, resulting in a higher (successful) uptake rate.

Timing of FonF was another variable mediating learners' production of (successful) uptake following target FSs vs. non-formulaic forms in FFEs. The immediate focus on FSs was a strong predictor of (successful) uptake when FSs where targeted in FFEs. On the contrary, the delayed focus on non-formulaic forms was a strong predictor of (successful) uptake when non-formulaic forms were targeted in FFEs. There are inconsistent findings on the efficacy of immediate and delayed FonF (e.g., Li, Zhu, \& Ellis, 2016; Quinn \& Nakata, 2017). Quinn \& Nakata (2017) argue that delayed FonF is effective in L2 development according to the distributed practice effect, indicating that longer intervals between attention to a form could lead to more effective long-term retention than shorter or no intervals. In contrast, Doughty (2001) posits that FonF is optimal when it occurs within 60 seconds of the trigger when humans can maintain active mental representations in the working memory. This study's findings suggest 
that the nature of forms in terms of formulaic vs. non-formulaic nature mediates the effectiveness of delayed vs. immediate FonF as measured by the successful uptake rate. Therefore, to promote learners' production of (successful) uptake, it is suggested that teachers use immediate and delayed FonF to address FSs and non-formulaic forms in incidental FonF, respectively.

Finally, the variables of complexity, directness, and emphasis were found to predict learners' production of (successful uptake) following FSs and non-formulaic forms in the same manner. Therefore, the findings of this study showed that some of FonF characteristics that predicted learners' production of (successful) uptake were different for formulaic vs. non-formulaic forms targeted in FFEs.

\section{Conclusion}

The present study investigated learners' production of (successful) uptake following FSs vs. non-formulaic forms in incidental FonF. Moreover, incidental FonF characteristics predicting learners' (successful) uptake of FSs vs. non-formulaic forms targeted in FFEs were examined. The findings showed that learners' attention was shifted to non-formulaic forms (61\%) more often than FSs (39\%) in FFEs. Nevertheless, learners produced successful uptake more often when FSs (66\%) were targeted in FFEs than non-formulaic forms (34\%). The higher rate of successful uptake following FSs could be ascribed to the greater saliency, noticeability, and communicative value of FSs (Wulff, 2019). In this study, teachers raised learners' attention to non-formulaic forms strikingly more often than FSs, while learners produced successful uptake markedly more often following FSs owing to the importance of FSs for communication. Therefore, in the light of these findings, it is suggested that teachers consider FSs as legitimate and essential targets among other linguistic forms and use incidental FonF opportunities to draw learners' attention to FSs as frequently as non-formulaic forms. The findings of this study suggest that teacher professional development programs raise pre-service and practicing teachers' awareness of the significance of FSs in communicative language use and the importance of incorporating FSs into incidental FonF practices.

Furthermore, the literature on formulaic language indicates that even advanced L2 learners are at a disadvantage to learn FSs due to the traditional emphasis on grammar and vocabulary in curriculum designs, materials development, and L2 pedagogy and assessment (Meunier, 2012; Wray, 2019). Given the significance of FSs for learners as indicated by their markedly higher successful uptake of FSs found in this study, it is suggested that FSs gain prominence in curriculum designs for L2 pedagogy as 
advocated by the proponents of chunk-oriented pedagogy (Meunier, 2012). Meunier (2012) attributed learners' inadequate knowledge of formulaic language compared to their knowledge of grammar and vocabulary partly to the paucity of corpus-informed materials. Corpus findings indicate that FSs are ubiquitous in language use (Erman \& Warren, 2000). Therefore, given the importance of FSs for learners in communication, as suggested by the higher successful uptake of FSs, it is recommended that a rich repertoire of FSs should be incorporated into materials developed for L2 pedagogy in line with corpus findings.

Another line of this study examined incidental FonF characteristics predicting learners' (successful) uptake of FSs vs. non-formulaic forms targeted in FFEs. The findings of logistic regression analyses revealed that incidental FonF characteristics in terms of the type of incidental FonF (reactive vs. preemptive FonF), timing of FonF (immediate vs. delayed), the source of FonF (problem with communication vs. problem with the accuracy of the form), and type of corrective feedback (output-prompting vs. input-providing) varied in predicting learners' production of (successful) uptake following FSs vs. non-formulaic forms. Immediate preemptive focus on FSs to address learners' problem with meaning rather than form and eliciting target FSs from learners through output-prompting feedback types were strong predictors of learners' uptake of FSs and successfulness of it. In contrast, delayed reactive focus on non-formulaic forms to address learners' problem with form rather than meaning and providing target non-formulaic forms for learners through input-providing feedback types were strong predictors of learners' uptake of non-formulaic forms and successfulness of it.

Hence, the findings of this study lend support to Loewen's (2005) conviction that "different kinds of focus on form might be needed for different aspects of language" (p. 382). Likewise, DeKeyser (2012) notes that different linguistic forms call for different needs for teaching. Ellis (2017) maintains that teachers make decisions on how to practice FonF, and they should do so in a principled manner. This study's findings suggest that teachers make informed decisions when focusing on FSs compared to non-formulaic forms and use different pedagogical options in terms of the types of FonF, timing of FonF, etc., in providing incidental FonF to promote learners' (successful) uptake of FSs and non-formulaic forms targeted in FonF. Finally, this study was conducted in an EFL context with advanced adult EFL learners. Future studies could offer insights into FonF practices by examining FonF characteristics that predict successful uptake of FSs vs. non-formulaic forms in other settings with learners from different proficiency levels. 


\section{Acknowledgment}

The author wishes to extend her gratitude to the teachers and learners who participated in this study.

\section{References}

American Council on the Teaching of Foreign Languages (2012). ACTFL proficiency guidelines. Retrieved from http://actflproficiencyguidelines2012.org/

Ayto, J. (2010). Oxford dictionary of English idioms (3rd ed.). Oxford, UK: Oxford University Press. doi: 10.1093/acref/9780199543793.001.0001

Benson, M., Benson, E., \& Ilson, R. (2010). The BBI combinatory dictionary of English: Your guide to collocations and grammar (3rd ed.). Amsterdam, Philadelphia: John Benjamins. doi: https://doi.org/10.1075/z.bbi.07dic

Biber, D., Johansson, S., Leech, G., Conrad, S., \& Finegan, E. (1999). Longman grammar of spoken and written English. Harlow: Longman.

Brown, D. (2016). The type and linguistic foci of oral corrective feedback in the L2 classroom: A meta-analysis. Language Teaching Research, 20(4), 436-458. doi: $10.1177 / 1362168814563200$

Buerki, A. (2016). Formulaic sequences: A drop in the ocean of constructions or something more significant? European Journal of English Studies, 20(1), 15-34.

doi: https://doi.org/10.1080/13825577.2015.1136158

Chomsky, N. (1965). Aspects of the theory of syntax. Cambridge, Massachusetts: MIT Press.

Clare, A., \& Wilson, J. J. (2016). Speakout (2nd ed.). UK: Pearson Education Limited.

Cohen J. (1960). A coefficient of agreement for nominal scales. Educational and Psychological Measurement, 20, 37-46. doi: https://doi. org/10.1177/001316446002000104

DeKeyser, R. (2012). Interactions between individual differences, treatments, and structures in SLA. Language Learning, 62, 189-200. doi:10.1111/j.14679922.2012.00712.x

Doughty, C. (2001). Cognitive underpinnings of focus on form. In P. Robinson (Ed.), Cognition and second language instruction (pp. 206-225). Cambridge: Cambridge University Press. doi: https://doi.org/10.1017/CBO9781139524780.010 
Egi, T. (2010). Uptake, modified output, and learner perceptions of recasts: Learner responses as language awareness. The Modern Language Journal, 94, 1-21. doi:10.1111/j.1540-4781.2009.00980.x

Ellis, R. (2017). Oral corrective feedback in L2 classrooms. In H. Nassaji \& E. Kartchava (Eds), Corrective feedback in second language teaching and learning: Research, theory, applications, implications (pp. 3-18). Routledge. doi:10.4324/9781315621432-2

Ellis, R., Basturkmen, H., \& Loewen, S. (2001). Learner uptake in communicative ESL lessons. Language Learning, 51(2), 281-318. doi: 10.1111/1467-9922.00156

Erman, B., \& Warren, B. (2000). The idiom principle and the open choice principle. Text, 20(1), 29-62. doi: https://doi.org/10.1515/text.1.2000.20.1.29

Gholami, L. (2021a). Incidental corrective feedback provision for formulaic vs. Non-formulaic errors: EFL teachers' beliefs and practices. Language Awareness, 1-32. doi:10.1080/09658416.2021.1943421

Gholami, L. (2021b). Oral corrective feedback and learner uptake in L2 classrooms: Non-formulaic vs. formulaic errors. Language Teaching Research, 136216882110215. doi: $10.1177 / 13621688211021560$

Gholami, L. (2021c). Incidental reactive focus on form in language classes: Learners' formulaic versus nonformulaic errors, their treatment, and effectiveness in communicative interactions. Foreign Language Annals, 1-26. doi: https://doi. org/10.1111/flan.12546

Gholami, L., \& Gholami, J. (2018). Uptake in incidental focus-on-form episodes concerning formulaic language in advanced adult EFL classes. Language Teaching Research, 24(2), 189-219. doi:10.1177/1362168818783442

Gholami, L., Karimi, M. N., \& Atai, M. R. (2017). Formulaic focus-on-form episodes in adult EFL communicative interactions. System, 68, 72-86. doi:10.1016/j. system.2017.06.015

Gurzynski-Weiss, L., \& Baralt, M. (2015). Does type of modified output correspond to learner noticing of feedback? A closer look in face-to-face and computer-mediated task-based interaction. Applied Psycholinguistics, 36, 1393-1420.

doi: https://doi.org/10.1017/S0142716414000320

Hosmer, D. \& Lemeshow, S. (2000). Applied logistic regression (2nd ed.). New York: Wiley.

Howarth, P. (1998). The phraseology of learners' academic writing. In A. Cowie (Ed.), Phraseology: Theory, analysis, and applications (pp. 161-186). Oxford: Oxford University Press. 
Hudson, J., \& Wiktorsson, M. (2009). Formulaic language and the relater categorythe case of about. In R. Corrigan, E. A. Moravcsik, H. Quali, \& K. M. Wheatley (Eds.), Formulaic language: Structure, distribution and historical change (pp. 77-95). Philadelphia: John Benjamins.

Kecskes, I. (2016). Deliberate creativity and formulaic language use. In A. Capone, F. Lo Piparo, \& M. Carapezza (Eds.), Perspectives in pragmatics, philosophy $\mathcal{E}$ psychology (pp. 3-20). doi:10.1007/978-3-319-43491-9_1

Li, S., \& Vuono, A. (2019). Twenty-five years of research on oral and written corrective feedback in System. System, 84, 93-109. doi:10.1016/j.system.2019.05.006

Li, S., Zhu, Y. \& Ellis, R. (2016). The effects of the timing of corrective feedback on the acquisition of a new linguistic structure. The Modern Language Journal, 100(1), 276-295. doi:10.1111/modl.12315

Loewen, S. (2004). Uptake in incidental focus on form in meaning-focused ESL lessons. Language Learning, 54(1), 153-188. doi: 10.1111/j.1467-9922.2004.00251.x

Loewen, S. (2005). Incidental focus on form and second language learning. Studies in Second Language Acquisition, 27, 361-386. doi: https://doi.org/10.1017/ S0272263105050163

Loewen, S. \& Sato, M. (2019). Instructed second language acquisition and English language teaching: Theory, research, and pedagogy. In X. Gao (Ed.) Second handbook of English language teaching (pp. 1131-1148). Springer Nature Switzerland. doi:10.1007/978-3-319-58542-0_60-1.

Long, M. (1996). The role of the linguistic environment in second language acquisition. In W. Ritchie, \& T. Bhatia (Eds.), Handbook of second language acquisition (pp. 413-468). San Diego, CA: Academic Press. doi: https://doi.org/10.1016/b978012589042-7/50015-3

Lyster, R. (1998). Recasts, repetition, and ambiguity in L2 classroom discourse. Studies in Second Language Acquisition, 20, 51-81. doi: https://doi.org/10.1017/ s027226319800103x

Lyster, R. (2001). Negotiation of form, recasts, and explicit correction in relation to error types and learner repair in immersion classrooms. Language Learning, 51, $265-$ 301. doi:10.1111/j.1467-1770.2001.tb00019.x

Meunier, F. (2012). Formulaic language and language teaching. Annual Review of Applied Linguistics, 32, 111-129. doi: https://doi.org/10.1017/S0267190512000128

Millar, N. (2011). The processing of malformed formulaic language. Applied Linguistics, 32(2), 129-148. doi: https://doi.org/10.1093/applin/amq035 
Myles, F., \& Cordier, C. (2017). Formulaic sequence (FS) cannot be an umbrella term in SLA. Studies in Second Language Acquisition, 39(1), 3-28. doi:10.1017/ s027226311600036x

Nesselhauf, N. (2005). Collocations in a learner corpus. Amsterdam: Benjamins. doi: $10.1075 / \mathrm{scl} .14$

Panova, I., \& Lyster, R. (2002). Patterns of Corrective Feedback and Uptake in an Adult ESL Classroom. TESOL Quarterly, 36(4), 573-595. doi:10.2307/3588241

Quinn, P. G., \& Nakata, T. (2017). The timing of oral corrective feedback. In H. Nassaji \& E. Kartchava (Eds), Corrective feedback in second language teaching and learning, (pp. 35-47). Oxon, UK: Routledge. doi:10.4324/9781315621432-4

Schmidt, R. (1995). Consciousness and foreign language learning: A tutorial on the role of attention and awareness in learning. In R. Schmidt (Ed.), Attention and awareness in foreign language learning (pp. 1-63). Honolulu, HI: University of Hawaii, Second Language Teaching \& Curriculum Center.

Siefring, J. (2005). The Oxford dictionary of Idioms (2nd ed.). Oxford: Oxford University Press.

Simpson-Vlach, R., \& Ellis, C. N. (2010). An academic formulas list: New methods in phraseology research. Applied Linguistics, 31, 487-512. doi: 10.1093/applin/amp058

Sinclair, J. M. (1991). Corpus, concordance, collocation. Oxford: Oxford University Press.

Siyanova-Chanturia, A. (2019). Formulaic language. In A, Siyanova-Chanturia, \& A. Pellicer-Sanchez (Eds), Understanding formulaic language: A second language acquisition perspective (pp. 1-15). New York, NY: Routledge. doi:10.4324/9781315206615-1

Swain, M. (1995). Three functions of output in second language learning. In G. Cook \& B. Seidlhofer (Eds.), Principle and practice in applied linguistics: Studies in honor of H.G. Widdowson (pp. 125-144). Oxford: Oxford University Press.

Warren, B. (2005). A model of idiomaticity. Nordic Journal of English Studies, 4, $35-54$.

Wood, D. (2020). Classifying and identifying formulaic language. In S. Webb (Ed.), Routledge handbook of vocabulary studies (pp. 30 - 45). Routledge: London.

Wray, A. (2019). Concluding question: Why don't second language learners more proactively target formulaic sequences. In A, Siyanova-Chanturia, \& A. PellicerSanchez (Eds), Understanding formulaic language: A second language acquisition perspective (pp. 19-37). New York, NY: Routledge. doi: https://doi.org/10.4324/97813152066151 
Wray, A., \& Namba, K. (2003). Use of formulaic language by a Japanese-English bilingual child: A practical approach to data analysis. Japan Journal of Multilingualism and Multiculturalism, 9(1), 24-51.

Wulff, S. (2019). Acquisition of formulaic language from a usage-based perspective. In A, Siyanova-Chanturia, \& A. Pellicer-Sanchez (Eds), Understanding formulaic language: A second language acquisition perspective (pp. 19-37). New York, NY: Routledge. doi: $10.4324 / 9781315206615-2$

Xu, J. (2015). Predicting ESL learners' oral proficiency by measuring the collocations in their spontaneous speech (Doctoral dissertation).Retrieved from http: //lib.dr.iastate. edu/etd/14875/.

Zhao, S., \& Bitchener, J. (2007). Incidental focus on form in teacher-learner and learner-learner interactions. System, 35(4), 431-447.doi: http://dx.doi.org/10.1016/j. system.2007.04.004 


\section{Appendices}

Appendix A: Criteria for the identification of FSs (adopted from Wray \& Namba, 2003: 29-33).

\section{Criterion}

Example

1. By my judgment, there is something grammatically unusual about this wordstring.

2. By my judgment, part or all of the wordstring lacks semantic transparency.

3. By my judgment, this wordstring is associated with a specific situation and/or register.

4. By my judgment, the wordstring as a whole performs a function situation and/or register

5. By my judgment, the speaker/writer has accompanied this of wordstring with an action, use of punctuation, or phonologica pattern that gives it special status as a unit, and/ or is repeating something $\mathrm{s} /$ he has just heard or read.

6. By my judgment, the speaker has marked this wordstring grammatically or lexically in a way that gives it special status as a unit.

7. By my judgment, there is a greater than chance-level probability that the speaker will have encountered this precise formulation before.

8. By my judgment, although this wordstring is novel, it is a clear derivation, deliberate or otherwise, of something that can be demonstrated to be formulaic in its own right.

9. By my judgment, this wordstring is formulaic, but it has been unintentionally applied inappropriately

10. By my judgment, this wordstring contains linguistic material that is too sophisticated, or not sophisticated enough, to match the speaker's general grammatical and lexical competence.

11. By my judgment, there is an underlying frame and one or more gaps in this wordstring. The frame is formulaic and the gaps can be filled with any lexical items.

$$
\kappa=.80
$$

rains cats and dogs, "rain" is intransitive

curry favor is non-compositional

I wonder if would mind ...

on the other hand

Idiomatic reading of pick-you-own vegetables

I have just learned pin money

false teeth

I slept like a twig instead of I slept like a log all's well that ended well outstay one's welcome

NP feel-TENSE ... to + infinitive

Note. $\kappa$ refers to the value of inter-coder reliability. 
Linguistic focus Description Example $\quad \kappa=.89$

Appendix B: Linguistic foci of formulaic FFEs (adapted from Xu, 2015: 86).

\begin{tabular}{|c|c|c|}
\hline Linguistic focus & Description & Example \\
\hline Example & & $\kappa=.80$ \\
\hline \multirow[t]{2}{*}{ A. The entire FS } & $\begin{array}{l}\text { Overall form, meaning, usage } \\
\text { of an FS, or }\end{array}$ & $\begin{array}{l}\text { S: كناهج هدكهد؟ /dehkæ- } \\
\text { deh dzæhnni:/ }\end{array}$ \\
\hline & $\begin{array}{l}\text { both lexical selection and lexi- } \\
\text { cal formation }\end{array}$ & $\mathrm{T}$ : global village \\
\hline B. Lexical selection & $\begin{array}{l}\text { The meaningfulness of combi- } \\
\text { nation of content } \\
\text { words in an FS. }\end{array}$ & $\begin{array}{l}\text { S: became daggers at me } \\
\mathrm{T}: \text { looked daggers }\end{array}$ \\
\hline 1. Unacceptable selection & $\begin{array}{l}\text { Deviation in the selection of } \\
\text { (a) content word(s). }\end{array}$ & $\begin{array}{l}\text { S: make a chance } \\
\mathrm{T} \text { : take a chance }\end{array}$ \\
\hline 2. Substandard selection & $\begin{array}{l}\text { Preference of a content word } \\
\text { over possible others }\end{array}$ & $\begin{array}{l}\text { S: It's very functional } \\
\text { T: yeah, fully functional }\end{array}$ \\
\hline C. Lexical formation & $\begin{array}{l}\text { Morphological elements in an } \\
\text { FS }\end{array}$ & \\
\hline \multirow[t]{2}{*}{ 1. Word form } & \multirow{2}{*}{$\begin{array}{l}\text { Inflectional and/or deriva- } \\
\text { tional deviation involving } \\
\text { substitution, omission, or in- } \\
\text { sertion of singular, plural, } \\
\text { restricted tense or morpho- } \\
\text { syntactic elements, etc }\end{array}$} & $\begin{array}{l}\text { S: I said "stick to your gun" } \\
\text { T: stick to your GUNS }\end{array}$ \\
\hline & & \\
\hline 2. Function word & $\begin{array}{l}\text { Deviation involving substitu- } \\
\text { tion, omission, or } \\
\text { insertion of a preposition, a } \\
\text { particle, etc. }\end{array}$ & $\begin{array}{l}\text { S: to hang off with friends } \\
\text { T: hang OUT }\end{array}$ \\
\hline 3. Determiner & $\begin{array}{l}\text { Deviation involving substitu- } \\
\text { tion, omission, or } \\
\text { insertion of a determiner. }\end{array}$ & $\begin{array}{l}\text { S: add insult to an injury } \\
\text { T: add insult to injury }\end{array}$ \\
\hline
\end{tabular}

Note. $\kappa$ refers to the value of inter-coder reliability. 
Appendix C: Syntactic patterns of lexical collocations (adopted from Xu, 2015: 80).

Type

$$
\text { (ADJ-N) }
$$

2. Adverb and adjective

(ADV-ADJ)

3. Adverb and verb

(ADV-V)

4. Noun-noun

$(\mathrm{N}-\mathrm{N})$

5. Noun of noun

$(\mathrm{N}-\mathrm{of}-\mathrm{N})$

6. Noun and verb

$(\mathrm{N}-\mathrm{V})$

7. Verb and noun

$(\mathrm{V}-\mathrm{N})$

8. Phrasal verb and adverb (PHV-ADV)

9. Noun and phrasal verb (N-PHV)

10. Phrasal verb and noun (PHV-N)
Examples

$$
\kappa=.86
$$

S: I hate crowded traffic

$\mathrm{T}$ : heavy traffic

S: It was clearly clear that

T: perfectly clear

S: I hugely advise using this

$\mathrm{T}$ : strongly advise

S: I want to know the first cause of it

$\mathrm{T}$ : we say root cause

S: a group of wolves

$\mathrm{T}$ : a pack of wolves

S: and lions barked

$\mathrm{T}$ : lions roar not bark!

S: and, I made photograph

$\mathrm{T}$ : made or took?

S: I had to wake early

$\mathrm{T}$ : wake up, right?

S: when sunflowers come

$\mathrm{T}$ : we say flowers come out

S: we have to adhere by rules

$\mathrm{T}$ : adhere to rules

Note. $\kappa$ refers to the value of inter-coder reliability. 
Appendix D: Patterns of grammatical collocations (adopted from Benson et al., 2010: XIX-XXX).

\begin{tabular}{lll}
\hline Type & Example & $\kappa$ \\
\hline
\end{tabular}

1. Noun and preposition (N-Prep)

2. Noun and to-infinitive (N-to-Inf)

3. Noun and that-clause (N-that-clause)

4. Preposition and noun (Prep-N)

5. Adjective and preposition (Adj-Prep)

6. Adjective and to-infinitive (Adj-to-Inf)

7. Adjective and that-clause (Adj-that-clause)

8. Verb and preposition (V-Prep)
S: comply by guidelines

$\mathrm{T}$ : comply with

S: I felt a compulsion ding it

$\mathrm{T}$ : a compulsion to do

S: I took an oath about abiding by the regulations

T: took an oath that you would abide by the regulations

S: I broke it based on accident

$\mathrm{T}$ : by accident

S: the plants are native in north of Iran

$\mathrm{T}$ : native to north of Iran

S: the accident was bound for happening

$\mathrm{T}$ : bound to happen

T: I was afraid to fail the exam

S: I was afraid that I would fail the exam

S: apologize from my sister

$\mathrm{T}$ : apologize to

Note. $\kappa$ refers to the value of inter-coder reliability. 
Appendix E: Taxonomy of lexical bundles (adopted from Simpson-Vlach \& Ellis, 2010: 37-42).

\begin{tabular}{lllll}
\hline Pragmatic function & AFL & Lexical bundle & FTW rank & $\kappa=.92$ \\
\hline A. Referential Expressions & Core & as a function of & 1.19 \\
$\begin{array}{llcl}\text { 1. Specification of attributes } \\
\text { a) Intangible framing attributes }\end{array}$ & Core & with respect to & 1.26 \\
2. Contrast and comparison & Written & on the other hand & 2.84 \\
& Core & as opposed to & 1.02 \\
3. Deictics and locatives & Spoken & at this point & 0.61 \\
4. Vagueness markers & Spoken & and so forth & 0.80
\end{tabular}

B. Stance Expressions
1. Hedges
Spoken
in a sense
0.56
2. Epistemic stance
Core
according to
0.18

C. Discourse Organizing Functions

1. Metadiscourse and
textual reference
Written
at the outset
0.51

2. Topic elaboration

a) Topic elaboration:

cause \& effect

Written

as a consequence

0.50

3. Discourse markers

Core

in other words

1.90

Spoken by the way

0.45

Notes. FTW stands for formula teaching worth. $\kappa$ refers to the value of the inter-coder reliability. 
Appendix F: Patterns of compounds (adopted from Wood, 2015: 47).

\begin{tabular}{lll}
\hline Type & Description & Example $\kappa=.95$ \\
\hline A. Closed form & The two components are written as one. & brainstorm \\
B. Hyphenated form & The two components are separated by hyphens.to & water-proof \\
C. Open form & The two components are written separately. & Bullet point
\end{tabular}

Note. $\kappa$ refers to the value of inter-coder reliability. 